Volume 3

Issue 3 January

Article 8

January 1976

\title{
Humanism as Demystification
}

Alfred McClug Lee

City University of New York

Follow this and additional works at: https://scholarworks.wmich.edu/jssw

Part of the Social Psychology and Interaction Commons, and the Social Work Commons

\section{Recommended Citation}

McClug Lee, Alfred (1976) "Humanism as Demystification," The Journal of Sociology \& Social Welfare: Vol. 3 : Iss. 3 , Article 8.

Available at: https://scholarworks.wmich.edu/jssw/vol3/iss3/8 


\section{HUMANISU AS DEYYSTIFICATION ${ }^{1}$}

by ALFRED MCCLUIC LES, Professor of Sociology Bmeritug, Brooklyn College and the Graduate School, The City University of New York

Under a variety of labels, many acadenic disciplines focus on the unsettling impact of fresh and vivid interpersonal experiences upon pre-existing beliefs and behaviour patterns. Reference is to philosophical discussions of sophism and hrmanism, historical theories about frontier influences, anthropological interest in culture shock, psychiatric concern with empathy and with perceptive listening, and sociological analyses of marginality, uses of participant observation and life-hiotory data, and clinical studies of social behavior. Their significant similarity is that they are all discussions of demptifying influences on social thought and action. They are derystifying in the sense that they tend to translate the diatant, the abstract, into imediate, specific, and personal terms. They throw traditional patterns into contrast with what is here and now and with quite different traditional formulations.

When this dematifying impact can be constructively absorbed, it moves individuals from-even tears them out of -a cultural context. It furnishes opportunities for the re-examination of value commitments, of ways of viewing oneself and others, of ways of behaving. It draws attention 'to the relative, unstable and conflicting character of political institutions, sogial usages, religious beliefs and even moral standards and ideals. 2 It makes for greater creativity and cosmopolitanism-wen it is constructively absorbed. It can stimulate others to pointless cynicise or rebellion.

One of the two fragments remsining from the extensive writings of Protagoras of Abdera is often said to encapsulate the fifth century B.C. humanist and sophist viewpoint: 'Man is the measure of all things, of the existence of things that are, and of the nonexistence of things that are not. 3 The first clause of this statement in particular has been echoed down through the ages by humanists as well as by their critics. In contrast with his own commitment to essences and absolutes, Plato quotes Socrates as speaking eatirically about sophists. He said they argued out of the 'superfluity of their wits.' Plato also has Socrates caustically pontificate that for Protagoras-secretly, among his own disciples only and not in statements 'to the common hex?" - 'all things are said to be relative - . out of motion and change and admixture all things are becoming relatively to one another, which "becoming" is by us incorrectly called being, but is feally beconing, for nothing ever is, but all things are becoming. ${ }^{4}$ This Platonic sneering, this anti-intellectualiam, is a sample of the inmuendos with which elitist philosophers have tried to destroy the teachings of such sophists as Protagoras, the one who 'gave a philosophic basis to Democracy. 5 
Who were these people? Those called sophists, the 'wise ones,' came to Athens some five centuries before our era and then later to Alexandria chiefly from the Greek frontiers in Ionia (Asia Minor) and Magna Graecia (South Italy). The settlers on those frontiers were adventurers and fugitives from wars against invaders of Greece. Generations there had had culture-stripping and culture-rebuilding experiences in their relations with diverse tribes. They had had direct participation in social change -in other words, clinical experiences with social and cultural reorganization-thrust upon them. This gave to at least a few a creative marginality in their intellectual stances, especially when they went to the great centers of commerce and learning. Theirs was intelligence coloured by culture shock, a reflection of perceptive listening to others from quite different backgrounds. They had participated in expanding trade and colonization, and in diverse personal intimacies that included exogamy. For them, traditional tribal values had been mediated or replaced by more cosmopolitan interpersonal and community identifications. The main mission of the sophists, as it appears in retrospect, 'was to teach, to clear up the mind of Greece, to put an end to bad moths and unproven cosmogonies, to turn thought into fruitful paths. . . The whole movement was moral as well as intelfectual, and was singularly free from . . corruption and lawlessness. 5 Toward the gods, the sophists could be at least agnostic. As Protagoras put it, 'With regard to the gods I cannot feel sure either that they are or that they are not, nor what they are like in figure; for there are many things that hinder sure knqwledge, the obscurity of the subject and the shortness of human life.'

Protagoras's ideas were as outrageous to the Platonists as they have been ever since to anxious seekers after dependable bases for authority upon which to erect controlling and controllable ideologies. 'The truly modern attitude towards most questions singularly resembles the general point of view of the Sophists. It has taken humanity well over two thousand years to recover from the influence of 8 post-Sophistic thought and to get back into this salutary frame of mind. ${ }^{\circ}$ Sophist ideas, such as those mentioned, contain the main thrusts of humanizing experiences, the experiences which have from time to time in human history contributed such invigorating and denystifying impacts upon social thought.

During its long subsequent history in social thought, humanism as a term has shared the following characteristics with those used to label other major generalities: It is shiftly, and it is sticky. It has had many definitions. It has been alleged to adhere to almost all sorts of other ideas, and it has also been shown to be opposed to each of them-whatever it was! These problems of the term can best be seen by realizing that it most accurately labels not a body of doctrine but a kind of mind-changing social experience. It is a recurrent ingredient in social movements, not a specific idea or social philosophy.'

$$
-348-
$$


Basic to this sense of humanism as humanizing experience are oneto-one confrontations and then friendships with quite different sorts of people. It depends upon those relationships being continuing enough and egalitarian enough to result in the development of a degree of efficiency in intercommunication and at the same time of a reciprocated ability to empathize. Granted such relatively intimate contacts, this type of experience tends to dissipate notions of personal and group superiority. It opens new perspectives on human talent and worth. It can even reveal to those who are patient the human bases upon which mankind has been stumblingly developing the beginnings of participant democracy.

Humanism has figured in a wide range of religious, political, and academic movements. As such, it has been identified with atheism, capitalism (especially of the laissez-faire brand), classicism, communism, democracy, egalitarianism, naturalism, positivism, pragmatism, relativism, science, scientism, socialism, statism, symbolic-interactionism, and supernaturalism, including versions of ancient paganism, Hinduism, Buddhism, Judai sm, Roman Catholicism, Protestantism, and Mohammedanism. It has also been rationalized as being opposed to each of these. It has served as an ingredient in movements against each. And these terms do not at all suggest all of humanism's ideological and social associations.

That humanism has had so many adventures is, on tire one hand, a tribute to the persistent human inclination to suspect or to perceive that the problems of life are actually human responsibilities-for better or for worse. This recurring tendency, on the other hand, has preoccupied generations of theorizers who have tried to anaestinetize the humanistically tempted into depending rather upon either a supernatural agency or, as that imagery has grown pale, upon an all-controlling natural order far beyond human control or manipulation.

When defined as simply and as etymologically as possible, humanism refers to 'thought or action in which humap, interests, values, and dignity are taken to be of primary importance.' 11 It is thus a preoccupation with what is most relevant, significant, and important to human beings. It is concerned primarily with individuals, with human expression and creativity, with human society and socializing, and with people's ability to persist and to flourish. This kind of thinking has emerged and has had great influence at times when international migrations and commerce were bringing people of diverse backgraunds into close contact with one another-in situations of participant observation and of perceptive listening. 
Along with supernaturalism and naturalism, humanism has been called 'one of three rival claimants to philosophic allegiance.' anthropomorphic agency, notions of an unconscious and automatically acting natural system, and notions of humanism are three germinal threads that run through recorded human thought. Fach implies a basis for its own authentication as well as a criterion for the rejection, reinterpretation, or incorporation of the two others. Since social theorists so of ten find it plausible and rewarding to mix two or three of these threads, their separate characters are difficult to detect, spell out, and aiscuss. To a degree, it must be done-if it is to be cone at all-rather arbitrarily, in terms of ideal types. At any rate, in its simplest notion, humanism humanism as a fresh and more accurate expression of interpersonal experience typically has implications unsettling to the status guo in any society. It is critical of ani often antagonistic to both supernaturalism and naturalism in their myriad forms. Esnecially in this century, humanism provides bases to criticize the dehumani-ing and epersonaljzing implications of both the natural sciences and absolutist metaphysics. When humanist perceptions are absorbed into a supernatural or a nature-centered ideology, they lose this annoyingly critical potential. In such an unstable mix, the composite can appear to become a prop for the status quo.

Supernaturalism concerns itself with ways to cope with aleatory elements in life through providing recourses to magical, spiritual, or divine powers. In toing so, it of fers explanations of life and nature that go beyond objective verification through sense experiences, that develop notions of a more or less integrated supernatural agency rationally in control and avallable for special dispensations to those satisfying the prescriptions of the related cult. Verification arises from fantasies, dogmatic claims, and coincidences. On such bases, adherents have erected poetic and powerful structures of theory, ritual 14 organization, enticing promises and services, and thus social control. With the growth of democratic and scientific tendencies, supernaturalists have also taken up selectei naturalistic rhetorics. This is an attempt to cope with the critical and anti-authoritarian potentials of existential humanism. Religion tius lecomes ilentifiei with human welfare on earth as well as in the hereafter, and scientific findings are claimed to be congruent with newly re-ratippalized divine laws. In this latter sense, 'natural law' is divine law.

Naturalism focuses upon the perception of nature ana the discovery of nature's laws. In this perspective, even though it be that of an enterprise necessarily carried on by and presumably for people, men and women have no special places within it. They are merely members of a passing animal species, sometime parasites on a small planet. Individual advocates of naturalism, in order to soften tie starkness of the view they put forward, often suggest icientities and relationships with supernaturalism and humanism. Impersonal nature thus becomes slightly anthropomorphized into something 'not too iifferent' $z s$ it were 
from 'enlightened views of divinity.' They may even use the term, God. Curiously enough, that anti-humanist advocate of naturalistic determinism, the psychologist B.F. Skinner, has so rationalized his behaviouristic position that he was hailed as ' 1972 Humanist of the Year' by $1 \bar{b}$ religious body calling itgplf the American Humanist Association. In Skinner's philosophy, 'What is being abolished [by the naturecentered] is autonomous man-the inner man, the homunculus, the possessing demon, the man defended by the literatures of freedom and dignity.' He approves this effort and has joined it as one of its leaders. Just how such a dedication can be squared with something to be called 'religious humanism,' with human aspirations and humanizing experiences, it is difficult to understand. Since people are admittedly parasites on a small planet, their preoccupation has to be with the needs of people in confrontation with cosmic processes, not merely with acquiescing to the mandates of those processes.

Both naturalism and humanism are necessarily based on scientific findings, as principal current exponents of both now contend. To emphasize this point, many humanists like to refer to themselves as scientific or naturalistic humanists in order togavoid confusion with Roman Catholic, Protestant, Jewish, or academic 'humanists.' The term naturalistic humanism does not at all imply an acceptance of such a position as that of Skinner. Both the nature-centered and the peoplecentered theorists interpret scientific findings in terms of their own needs and aspirations. The egalitarian and libertarian temptations of humanist experiences and their demonstration of the relativity of values to individual, group, and changing subculture and culture scare many psychologically and socially insecure people. Like supernaturalism, nature-centeredness places responsibility outside the individual, outside of humanity. The will of God becomes the consequence of natural processes as perhaps revealed by 'the utterly impersgnal problem solutions of the computer,' to quote $R$. Buckminster Fuller's 20 naive statement of faith. Fuller then adds: 'Only to their superhuman range of calculative capabilities can and may ałl political, scientific, and religious leaders face-savingly acquiesce. ' $2 \nmid$

Humanism is heady stuff. As social experience, it can tempt thoughtful men and women to throw into question their cultural heritage of supernaturalism or nature-centeredness as an exclusive or predominant frameof-reference for thought and action. When they attempt to do so, however, they often try to carry along as much of their previous intellectual baggage as they can, and this of ten confuses their new orientation to life and living. Compromise statements compound themselves and eliminate the controversial and even revolutionary aspects of the humanist temptation. Belief in the controlling power of the supernatural is so great that many skeptical theorists, vith little or no faith in a deity themselves, agree with Nicolo Machiavellice $(1469-1527)$ that 'there is no greater indication of 
the ruin of a country than to see religion condemned.' He asserted that, with rulers maintaining religious forms in a convincing manner, 'it is easy to keep their people religious, and consequently well conlucted and united.' It was only with the emergence of a statist need for unity in spite of religious diversity that that child of the eighteenth century Enlightenment, the United States of America, Iinally adopted the separation of church and state as a constitutional principle. ${ }^{23}$ Thomas Jefferson, the provision's main sponsor, had reduced divinity in his own thinking to abstract naturalism labeled theism. Actually, in effect, a secular religion of statism was to replace such awkward and outworn instruments of control as the Church of England. As is currently evidenced by the religious-sectarian colourations of struggles in Northern Irelanù, in Canada, and even in the English and Scottish industrial cities, the British have yet to follow that United States prececient; as imperfectly implemented as it is in the ${ }_{2}$ United States, it has freed the country from much anguish in such terms.

As has been indicated, the dawn of the historical meanderings of humanism is usually placed, for lack of more ancient documentation, in the Greece of the fifth century before our era. As taught by the sophists, humanism gave much of Greek literature its people-centered and universal character. After humanism's great days in Athens and in Alexandria, its second and more continuing center, there are jumps to the Muslim and Jewish flowerings in North Africa during the fourteenth century and to Italy during the fourteenth and fifteenth centuries. Greek learning and the findings of such inveterate travelers, readers, and commentators as Ibn Batuta and Ibn Khaldun made the 2 lorth Africans a bridge between the humanist past and the Renaissance. Dante, Petrarch, Boccaccio, and others expressed humanist views in part through reviving interest in the Gregk classics and in part through their own imageries and theories. 7 But in those periods, in the Englightenment of the eighteenth century, and in recent humanist-oriented literature, painting, philosophy, social science, and even 'religion,' humanism has resisted thoroughgoing conceptualization as a philosophical system. It has not yielded such systemic constructs as have supernaturalism and naturalism. on the contrary, it has frequently intruded on such system-builiing and unsettled or even destroyed it. This demonstrates the critical and processual character of humanizing experiences and humanist philosophizings. It is accurately ana inclusively seen as an intellectual and social process. It is a consequence of intimate exposure to iiverse types of human beings. It arises out oi human empathy and sympathy, out of an awareness of common humanity and a common fate. It is an unioldiing of a

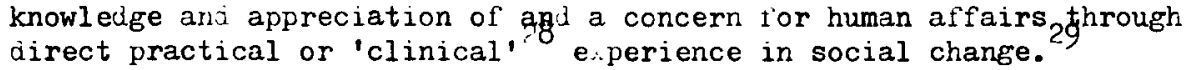

This may all seem very well when viewed historically and in rather ahstract terms. what does it mean in social tinought toiay? 
Why is humanism still so controversial even among students of human sciences such as sociology and social psychology? What does it do to the security some of us find in pretentious methodologies, fancy terminologies, and elegant theoretical constructs? Let us get at these questions by looking briefly at five somewhat related social developments, all called 'humanist.' These are: (1) liberal humanism, (c) Marxian communism, (3) 'religious' humanism, (4) humanistic psychology, and (5) humanist sociology. It is useful to discuss the first two--liberal humanism and Marxian communism-as background for the other three--'religious' humanısm, humanistic psychology, and humanist sociology--because the latter arose out of the former and have problems somewhat similar to them. Theje is no point in our going so far afield as to discuss Roman Catholic 38 and Protestant 3 ' humanism.' It would be much more relevant to add a discussion of the impact of humanizing experiences on painters and of humanist fine art upon social perception generally. From Pieter Bruegel (1525-1569), El Greco (Domenikos Theotocopoulos, 1541-1614), William Hogarth (1697-1764), and Francisco de Goya (1746-1828) to Diego Rivera (1886-1957) among the many great moderns (including newspaper cartoonists) $\overline{2}^{-t o}$ mention only a $f$ ew superb examples-the record is most impressive.

1. Liberal humanism became, in the nineteenth century, a recourse of intellectuals who were repelled both by communism and by naturalistic evolutionism as a justification for unbridled "free enterprise" capitalism as well as by supernaturalism. The position was and is a complicated one. It is compounded of values traditionally embedded in European-American middleclass ideals. These values glorify compromise, gradualism, civil liberties, and fair play. They are the values of those why would be both societal stabilizers and surrogates of societal morality. 33 In consequence, its adherents find its more outspoken and critical exponentsalbeit non-communist and non-capitalist-extremist-difficult bed fellows. Illustrations of such thorny spokesmen are Anatole France (Antole Francois Thibault, 1844-1910). By contrast with their more culture-bound contemporaries, they help to characterize liberal humanism. Uthers who would be equally useful as examples are John Dewey (1859-1952), Thomas Mann (1875-1955), Albert Einstein (1879-1955), and Albert Camus (1913-1960), to mention but a few of the many.

France and Twain had had deep and varied humanizing experiences that led them to rethink radically the views they had received as to man's lot and then to bespeak their criticisms of society and of man as they found them. Neither was handicapped much by formal education. France finally did pass his esaminations for the university laureate, but his preparation was largely informal; he browsed in his father's bookstore and talked with all sorts of people in Parisian cafes and streets. Twain, on the other hand, was a gradeschool dropout who educated himself in newspaper shops, river boats, bars, billiard parlors, and mining camps, and through all sorts of reading. As each 
grew older, his disillusionment with the status quo and his compassion for the orrressed and for all mankini increaser. Fach criticized not only avowe upholders of outworn social institutions but also other libedal humanists who took compromising stances. Toward the end, France even turred his back upon liberalism and became a communist. As human affairs have grown more chaotic in this century, liberal humanists have multiplied in numbers, and many have become increasingly caustic and radical. (For

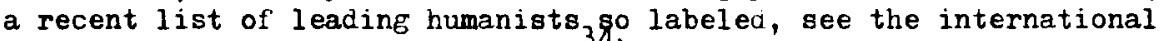
signers of "Humanist Manifesto II. ${ }^{34}$ )

In the great French tradition of Rabelais, Montaigne, Moliere, Voltaire, and Renan, France gloried in his skepticism. As he saw it, 'The word is used as synonymous with negation and futility. But our great skeptics were often the most affirmative and courageous of men. They repudiate only negations. They attack those who tramel intelligence and will. They fight against ignorance which debases, against error which oppresses, against hate which kills. . . . The most skeptical of thinkers, meditating on the futility of the eternal flux of the universal, on the ineffectualness of poor mankind and on the absurd sufferings which it inflicts on itself during its brief, dreamlike existence, are filled with a profound compassion for their fellows. From this compassion to a fraternal love is but a single step. Their pity is stirred, and those who believe themselves forever detached from everything lose themselves in the combat to rescue their unhappy brothers.' 35 Such was the credo and apologia pro suavita of one of the greatest of French novelists, the author of Penguin Island (1908) and of The Revolt of the Angels (1914), a staunch defender of Captain Alfred Dreyfus, and an opponent of World War I. Interestingly enough, both France and Twain were authors of books dealing with Joan of Arc--as was that other skeptical humanist, George Bernard Shaw. Her glorification of the human spirit, her willingness to confront the decadence of church and state, thrilled them all.

In a sense, Twain was the greatest and most authentic product in literature of the American frontier. As background for him, it is instructive $\frac{f g}{6}$ think of the significant parallel drawn by the historian F. J. Turner': 'What the Mediterranean Sea was to the Greeks, breaking the bond of custom, offering new experiences, calling out new institutions and activities, that, and more, the ever retreating frontier has been to the United States directly, and to the nations of Europe more remotely.'

Life France, Twain built his popular fame upon his virtuosity as a storyteller. His thoroughgoing people-centeredness was the special ingredient withyhich he, like France, permeated all of his writings. As with Prarice, 'Wain's stenticism made 3 many intellectuals and even many liberal humanists react unfavorably. ${ }^{38}$ The author of Tom Sawyer 
(1876) and Huckleberry Finn (188̧6) also wrote What Is Man? (1904) and The fysterious Stranger (1916), 39 two books that emphasize the profundity of his 'children's books.' As the leading analyst of Twain's work notes, 'He was not merely the artist of American youth and the past; he was surely our most mature and wisest of artists whose acerbity and profundity alike were ringed about with the imperishable comic spirit. In his age he only became freer, bolder, more open and honest, more emancipated both socially and sexually, from the taboos of his epoch which, at base, his spirit had never accepted."

Many of those who have attempted in this century to shape what they call secular and liberal humanism differ from such "irresponsible" writers as France and Twain. The philosopher F.C.S. Schiller 41 (1864-1937 tried to create an academically respectable humanism. He identified his doctrine as a variant of pragmatism, the movement launched by Charles $S$. Peirce (1839-1914) and William James (1842-1910). His humanism 'was essentially,' as he said, 'a protest against the dehumanizing and depersonalizing procedure which seemed to characterize both the natural sciences and absolutist metaphysics.' He located his metaphysics "intermediate. . - between naturalism and supernaturalism" and came to substitute the term voluntarism for humanism as a label for his philosophy. On the other hand, such writers as the essayist Paul Elmer More (1864-1937) and the scholar Irving Babbitt (1865-1933) shied away from the unsettling egalitarian implications of humanism. Both preoccupied thenselves with the problem of order and its maintenance in social relations. They sought compulsions toward such order in mystical inner experiences similar to those of religious devotees but stimulateg, nontheologically by tradition, interpersonal relations, and thought. ${ }^{42}$ The contributions of Schiller, More, and Babbitt to the humanist movement in social thought have thus not been weighty.

2. Marxian communism had among its humanist starting points G.F.W. Hegel's 'exaltation of man's endeavor "to understand the world, to appropriate and subdue it to himself" 'ang his 'clear willingness to commit the sin of pride on behalf of man. 13 It also owed much to Karl Marx's own awareness of how the proletariat had performed during the French Revolution. Marx observed that the proletariat no longer need be written off as dependent and deferential. He took it to be the aggressive and dependable instrument for the revolutionary otherthrow of capitalism.

The increasingly popular appeal of natural science and its freedom from ecclesiastical controls apparently made naturalism most enticing to Marx. In his early exuberance, he asserted: 'Communism as a fully develope naturalism is humanism and as a fully developed humanism is naturalism. It is the definitive resolution of the antagonism between man and nature, 
and between man and man. 44 He arrived at this view by claiming that 'atheism is humanism mediated to itself by the annulment of religion, while communism is humanism mediated to itself by the annulment of religion, while communism is humanism mediated to itself by the annulment of jrivate property. 14 At this early stage, Marx thus appears to be people-centered and not yet to have moved on to a nature-centered societal determinism. It was in this early period of humanist pre- 46 occupation that Marx and Engels wrote their famous German Ideology, based upon 'men, not in any fantastic isolation or abstract definition, but in their actual, empirically perceptible process of development under definite conditions.' This vigw made history cease for them to be 'a collection of dead facts. 47

Two involvements appear to have diverted Marx from following out fully and without compromise implications of a people-centered orientation. These were (1) his vocation as an agitator for social change 48 and (2) his evident conviction that human considerations do not provide in themselves adequate bases for ideological authority or allegiance, that he also needed-or had to accept-what he took to be the mandates of an overriding scientific naturalism.

Marx's vocational complication led him to such contentions as that the revolution of the proletariat should best and most likely begin in the British Isles. As he asserted: "The Finglish have all the material prerequisites necessary for the social revolution. What they lack is the spirit of generalization and revolutionary fervour.' He predictei that an Irish reyglt would provide the starting point and leverage for

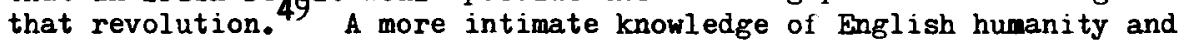
its accumblated and internalized social controls would have made him far less optimistic in his assessment of his vocatiogal opportunities to agitate revolution successfully in that country. $50^{2}$ That communist revolutions would succeed in such relatively undeveloped countries industrially as Russia and China was apparently not seriously entertained by Marx and Engels.

Once Marx had mixed nature-centeredness or nature-determinism and its imperatives (as he saw them) with his humanism and had given them greater weight than the people-centered, he visualized historical processes as having sufficient precedence over individual rights and wishes to achieve the transformations of society he thought to be necessary. This gave his philosophy a kind of dehumanizing determinism in his more 'mature' phase. 5 As he summarizes its, his dialectical process 'regards every historically developed social form as in fluid movement, and therefore takes into account its transient nature not less than its momentary existence; . . it lets nothing impase upon it, and it is in its essence critical and revoluticnary. 's? 
Nurtured by such skeptics as France and Twain and by such revolutionary theorists as Marx and Engels, humanism survives in an increasingly objective and radical form to become the significant ingredient in European-American intellectual currents. Three of its developments, now to be briefly examined, have many of the problems of both liberal and Marxian humanism. These problems are chiefly the temptations of scientistic naturalism and of the forcing of a redefinition of the middleclass molds in which many of humanism's spokesmen have been shaped and thus intellectually limited and even distorted.

3. Religious humanism is an organizational offshoot of liberal humanism, born chiefly of a need felt by educated parents to provide their children with a substitute for supernaturalist church schools. It has grown as a friendly heresy within the Unitarian-Universalist denomination. In addition to those congregations and fellowships of the Unitarian-Universalist denomination which are avowedly humanist, religious humanism's most eccelsiastical manifestations are the Ethical Culture Societies and the local units of the American Humanist Association. 53

As with Yarxians, many religious humanist spokesmen have both naturedeterminist and vocational biases. These biases complicate even further their middleclass anxiety to be respectably plausible to many people and to gain a kind of legitimacy through identifying with societal morality as they interpret it, a morality of the 'future.'

Reference has already been made to the nature-centered bias exhibited in an official act of the American Humanist Association. Readers of that organization's periodical, The Humanist, which is also the organ of the Ethical Culture Socjeties, find it to be a persistent theme. In contrast, Curtis $W$. Reese ${ }^{54}$ as a respected leader of the general movement clearly observes that religious humanism 'has withstood tons of volumes designed to show how man is in the grip of fate, or subject to the iron law of physical determinism, or molded by purposes of which he is unaware, or blown like a broken reed by the winds of the centuries.' He affirms that 'the nature of the world is such that human intention and activity may play the determining role in human enterprise, subject only to the conditioning factors of the environing situation.'

The vocational bias of religigps humanists is a more subtle problem. Concern with it leads Paul Blanshard 55 to warn against bringing 'humanism under the sentimental, all-purpose umbrella of religion.' He wants humanists rather to dedicate themselves to the promotion of such useful projects as birth control, including abortion at will, and legal equality for unbelievers and to the struggle against parachiaid (tax support for parochial schools) and prayer and Bible-reading in tax-supported schggls. He opposes such efforts as that of the philosopher J.H. Randall, Jr. to expand the vocation of the religious humanist to include 'the humanistic 
interpretation of traditional religion.' Randall wants 'to bring into the forefront the relatively humanistic core that has been overlaid with supernatural ideas.' Perhaps even though such efforts as that proposed by Randall are likely to be so sloppy as to be indefensible intellectually, they have their uses in social therapy, in the continuing struggles to liberate the minds of people. 57

Religious humanist organizations have remained small, but their their relations with the great humanist intellectual and social movements and their contacts with organized religion have made them bridges of interpretation. Their greater freedom to take up proposals for social changes has made their spokesmen sources of ferment in religious thought and sccial philosophy. They have thus helped to provide liberal humanism's creative voices with broader audiences and with a degree of organizational support with which to withstand supernaturalist and other pressures.

4. Humanistic psychology is the creation of scientists influenced by the liberal humanistic tradition and by their own humanizing experiences, who have been nagged by questions of the relevance of their discipline's findings to the solution of everyman's human problems. It has roots in the pragmatism of Peirce and William James and in the psychic probings of Sigmund Freud, his followers, and some of his antagonists. In part, it became a reaction against the biological determinism of such writers as Julian S. Huxley ${ }^{9}$ who saw humanism as a call to man 'to do the best he can to manage the evolutionary process on this planet and to guide its future course in a desirable direction.' To accomplish this, he said, 'fuller realization of genetic possibilities becomes a major motivation for man's efforts, and eugenics is revealed as one of the basic human sciences.'

In a debate, Carl Rogers as one of the principal current proponents of humanism in psychology agreed with B.F. Skinner 'that the whole question of the scientific control of human behavior is a matter with which psychologists and the general public should concern themselves.' As the sciences of biology and psychology develop, they are exhibiting frightening potentialities. Rogers focused his differences with Skinner on answers to these questions: 'Who will be controlled? Who will exercise control? What type of control will be exercised? Most important of all, toward what end or 60 what purpose, or in the pursuit of what value, will control be exercised? 60

For Skinner, the answers to these questions lie within the mystique of science and scientists. He asserted: 'I cannot quite agree that the practice of science requires a prior decision about goals or a prior choice of values.' Whether or not such a choice is required, he does not weigh adequately the significance of the fact that such choice is made either for or by the would-be scientist. It is never dodged. The unwitting acceptance of culturally or organizationally set goals is scarcely to be 
condoned in social science as a basis for avoiding responsibility in the name of an illusory value-free ethical principle. Skinner contends that when we trust scientists the whole problem of the control of power is really on its way to being solved for the greater good of human survival. 'If we are worthy of our democratic heritage we shall, of course, be ready to resist any tyrannical use of science for immediate or selfish purposes. 161 By the time such 'tyrannical use of science' becomes obvious to anyone, however, controls developed by psychologists or biologists might well have rendered mass resistance impossible. 62

On the other hand, Rogers is vividly aware that scientists are people. He recalls how German rocket scientists worked for the Nazis and then for whichever major power-U.S.S.R. or U.S.A.-captured them. As Rogers notes, 'If behavioral scientists are concerned solely with advancing their science, it seems most probable that they will serve the purposes of whatever individual or grouf has the power.' In other words, 'the scientific control of human behavior' would be in grave danger of 'the denial, misunderstanding, or gross underestimation of the place of ends, goals or values in their relationship to science.' Rogers therefore contends that the choice of values 'will forever lie outside the science which implements them; the goals we select, the purposes we wish to follow, mast always be outside of the science which achieves them. To me this has the encouraging meaning that the human person, with his capacity of subjective choice, can and will always exist, separate from and prior to any of his scientific undertakings.' 63

So as not to make these comments on a complex and promising humanist defelopment too long, another exponent can be quoted. Sidney M. Jourard 44 contends: 'When researchers are transparently pledged to further the freedom and self-actualizing of their subjects, rather than be unwitting servants of the leaders of institutions, then they will deserve to be and to be seen as recipients of the secrets of human being and possibility.' He adds: 'This is not the death of "objective," scientific psychology. Rather, it may prove to ge the birth of a scientifically informed psychology of human persons.'

5. Humanist sociology is not new. Like humanistic psychology, it is an offspring of intimate interpersonal experiences, of nagging problems of scientific relevance to everyman's human concerns, of the liberal humanist movement, and of a scientific ethic dedicated to the satisfaction of curiosity and of desire to serve people rather than merely to build a profitable cult. Like liberal humanism generally, it has had a constant struggle with the limiting influences of middleclass ideals, mores, and organizations as well as with pressures from other classes. It has also benefited from those ideals, mores, and organizations as well as from those pressures, especially from the pressures of the less well-placed classes. Those who have tried to push sociology toward a humanist orientation have had to confront the seductions of special interests, of scientism, of sentimentality, of humane panaceas, of irrelevant but prestigious methodologies, and of pretentious theoretical fretworks. 
Many

They have done 5 . ir sri

life-hictory materials, perceptive listcning, social behavior through personal involvement in social planning and action. 66

In his famous study of London at the end of the nineteenth century, Charles Booth's 5 frat contributions were not his statistics, according to Robert E. Park 'but his realistic descriptions of the actual life of the occupetional classes - the conditions under which they lived and labored, their paesions, pastimes, domestic tragedies, and the life-philosophies with which each class met the crises peculiar to it.' Booth's descriptions 'made these studies a memorable and a permanent contribution to our knowledge of human nature and of society.' Such accurate and intimate data helped to demystify London slums; they made more realistic thinking about them possible.

Extensive participant observation, perceptive listening, and clinical experience in social action convinced W.I. Thomas that he could not 'believe in. - comparisons between physics and sociology,' in other words in scientisn; 'you never have the same experimental control of a situation.' The sociologist has to be satisfied with 'high degrees of probability.' 'Thomas's studies of intimate life-histories and of their contexts ard his fiscr.nal involvement in social struggles led him to that demystification of sociological research that lent such distinction to his career. To quote him again: 'The case study method and the "natural history" method must not only precede the more scientifically acceptable method in order to produce realistic hypotheses and indicate what units should be defined and isolated; they must also be used as a ceneral background of reference th the more limited statistical findings, which lead - - to inferences which must be constantly chggked for validity against the large mass of material not yet analyzable. 19

Participant observation, perceptive listening, and experiential involvement in social action are old, somewhat recognized, but difficult procedures to employ in social exploration, critical re-evaluation of social theory, and theory modification. Basically, their advocates counsel: Sit down and talk with people with quite different backerounds from your own. Then, and above all, see how they actually behave in significantly challenging social action situations. Try to comprehend how the other persons sense their lives, thoughts, social worlds. This takes time, patience, and more than a little mind-stretching. Put aside as much as you can, they suggest, the common exercise of self-congratulation that you are not as your interviewees are-not so bound by tradition, so stupld, so gullible, so manipulated by the mass media, so inadequate, so 'disturbed,' so 'platholcEical.' As the advocutes of these metlods advise, try gently tc hel, muformants fcrget their isychological barriers

$$
-3611-
$$


against self-revelation. This can take place concomitantly with your own breaking down of your own barriers against hearing and understanding in their terms what those interviewed have to tell you. Then attempt to conceive as well as you can what it would be like to be living those other persons' lives. Sometimes this can only be done, to the ertent that it can be done, by working with them as equals to cope with mutually recognized social problems.

How many have had mind-stretching experiences such as $\mathrm{W} .7 \delta^{\circ}$. Whyte went through when he was working on his Street Corner Society in South Boston? Recall what complicated procedures he planned for his study, the research team he thought he would need, all the rest, and then how instead he went into the field alone and began his clinical study of the social behavior in which he came to participate. His head many times ached from culture shock, but he learned far more than he might have had he carried out his a priori plan of research. His book vividly introduces its readers to the highly organized life of an ItaloAmerican neighborhood.

After such humanizing experiences, the stereotyped ideas with which we 'handle' a different sort of person start to crumble. The black business operator or migratory Chicano worker or American Indian militant or even the colleague in a different specialty or status talks quite differently about many things than we do, but the longer and more candidly we converse the more sense that talk makes. Through an egalitarian search for common goals, males and females might open up new worlds of understanding of the other sex, but this does not often happen. We do not enter into such a relationship in an egalitarian manner, and thus we do not have opportunities to depart from stereotyped role patterns in our speaking and hearing. We hold fast to our sex roles and sex stereotypes. A pimp or a thief or a homoserual or a drug pusher or a schizophrenic can reveal worlds of 'reality' that make our own worlds take on surprisingly altered characters-bocial scientists though we might be. No wonder that a whole rash of new discussions of psychotherapy exploits the consequences of ney/levels of perceptive listening to individual problem-racked people.

What is so unusual about the humanizing experiences obtained in participant observation, perceptive listening, and the clinical study of social behavior? Are not at least the first two well entrenched in the texts on social research methods? Are they not even something of a current fad again in social problems research in spite of propaganda by scientistic positivists that they are more journalistic than 'scientific'? Why are these methods so consistently opposed or defined into useless rigidity by proponents of scientism, commercialization, and academic bureaucratization? Have not realistic novelists, careful journalists, and ethnologists given these procedures vivid exemplification and interpretative validation for many years? 
The stress here is not just upon the usefulness of these procedures in an occasional research project. They are basic to the processes of humanizing and demystifyins all social thought in a tradition that stretches back to the Greek sophists. This is not at all to suggest the rejection of such widely held scientific criteria as accuracy, representativeness, $75^{e l e v a n c e, ~ i n t e r n a l ~ c o n s i s t e n c y ~ r e p l i c ̧ b i l i t y, ~ a n d ~ c l a r i t y ~}$ of statement. 72 On the contrary, as Glenn Jacobs 73 points out, 'Such a view presumes a radical empiricism in place of scientism, a disciplined skepticism about any substitute for man as his own measure.'

Perceptive involvement in social action, with its products of culture shock and intellectual marginality, is our basic humanizing and demystifying influence in social thought about people and society. Even specialists in ancient history or extinct languages see a new vibrancy in their subjects from expanding their experiences with living individuals and groups. The students of current oocial affairs who return from their field work to their libraries and computers are not the same as the ones who went forth. Fortunately, for all their simplicity and for all their utter complerity, these humanizing procedures constantly press fresh views of changing humanity and society upon the attention of those engaged in thinking about the human lot. 
Notes

1Reprinted by permission of the Editor, Arun Sahay, from Sociological Analysis \& Theory, Vol. V, No.3 (October 1975).

The author is indebted for critical comments on this manuscript by Sidney Aronson, Henry Etzkowitz, Howard and Lenore Henderson, Mark Hutter, Glenn Jacobs, and Elizabeth Briant Lee. This paper was read before the Irish Sociological Association, Jublin, April 4, 1975.

2B.A.G. Fuller, 'Sophists,' Encyclopedia of the Social Sciences, XIV $(1934), 259-261$, at 259.

${ }^{3}$ Quoted by Socrates in The Works of Plato: Abridged, ed. Irwin Edman (New York: Simon and Schuster, 1928), 473.

${ }^{4}$ Ibid., 474 .

${ }^{5}$ Gilbert Murray, A History of Ancient Greek Literature (New York: Appleton, 1897; re-issued: New York: Frederick Ungar Publ. Co., $1966), 163$.

${ }^{6}$ Ibid., $163-164$

${ }^{7}$ Quoted by Moses Hadas, A History of Greek Literature (New York: Columbia University Press, 1950), 80 .

8 Harry Elmer Barnes, An Intellectual and Cultural History of the Western World, 3rd ed. rev. (New York: Dover Publications, 1965), 131.

9.McC. Lee, Toward Humanist Sociology (Englewood Cliffs, N.J.: Prentice-Hall, 1973), ix-xii; Paul Blanshard, 'Communication,' The Humanist, XXXIII, 2 (March-April 1973), 36.

10 Herbert Blumer, Symbolic Interactionism: Perspective and Method (Englewood Cliffs, N.J.: Prentice-Hall, 1969).

11

The Random House Dictionary of the English Language, col. ed. (New York: Random House, 1968), 645; cf. The Century Dictionary, rev. ed. (New York: Century Co., 1914), 2913, and The Oxford Finglish Dictionary, rev. ed. (Oxford: Clarendon Press, 1933), I, 44 . 
12E.P. Cheyney, 'Humanism,' Encyclopedia of the Social Sciences, VII $(1932), 537-542$, at 542 .

13 F.C.S'. Schiller, 'Humanism,' Encyclopedia of the Social Sciences, VII $(1932), 542-544$, at 543.

${ }^{14}$ Andrew D. White, A History of the Warfare of Science With Theo-

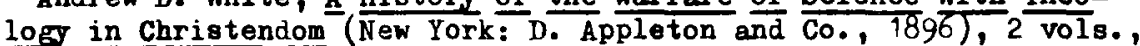
W. G. Sunner and A. G. Keller, The Science of Society (New Haven: Yale University Press, 1927), II.

15W. H. Coates and others, The Emergence of Liberal Humanism (New York: McGraw-Hill Book Co., 1966), Chap. 6 .

${ }^{16}$ Corliss Lamont, 'Highlights of the Humanist Movement,' The Humanist, XXXV, 1 (January-February 1975), 52-53.

17 B. F. Skinner, Beyond Freedom and Dignity (New York: Bantam Books, 1971), 191.

18 Lee, 'Communication', The Humdinist, XXXIII, I (JanuaryFebruary, 1973), 46.

${ }^{19}$ The term, academic, is added because classicists and other specialists in 'humane letters' have long been called 'humanists.' This is an inheritance from the fifteenth century Italian distinction between the study of the sacred (studia divinitatis) and of the humane (studia humanitatis), the humanities. See Coates and others, op.cit., 4 .

${ }^{20}$ R. B. Fuller, Operating Kanual for Spaceship Earth (Carbondale, Illinois: Southern Illinois University Press, 1969), 36.

${ }^{21}$ Cf. Lee, 'Garbage out,' in his Toward Humanist Sociology, op.cit., 21-23.

${ }^{22}$ Niccolo Machiavelli, 'The I'iscourses,' trans. C.E. Tetmold, in: The Prince and the Piscourses (New York: Modern Library, 1940), $\frac{14}{149}-\frac{\text { ringe }}{150}$

23J. L. Blau, ed., Cornerstones of Religious Freedom in America (Boston: Beacon Press, 1949). 
24E. R. Clinchy, All in the Name of God (New York: John Day Co., 1934.

25 Moses Hadas, op. cit., chap. 13.

${ }^{26}$ G. E. von Grunebaum, Medieval Islan (Chicago: University of Chicago Press, 1936); Franz Rosenthal, 'Ibn Khaldun's Life,' in Ibn Khaldun, The Yugaddimah, trans. Resenthal (New York: Pantheon Books, 1958), I, xxix-lxvii.

${ }^{27}$ Coates and others, op. cit., chap. 1.

${ }^{28}$ Reference here is not to a medical "clinic," but to a similarly instructive, actual social situation.

${ }^{29}$ Lee, Multivalent Man (New York: George Braziller, 1966), chap. 22.

30 Jacques Maritain, Existence and the Existent, trans. Louis Galantiere (New York: Random House, 1949).

${ }^{31}$ Reinhold Niebuhr, Nature and Destiny of Man (New York: Charles Scribner's Sons, 1949), I-II; Paul Tillich, Courage to Be (New Haven: Yale University Press, 1952).

${ }^{32}$ Glenn Jacobs, 'Convergences of Artistic and Sociological Insight in the Paintings of Pieter Bruegel,' Sociological Abstracts, XX, 6 (October 1972), xxv-xl.

33 Lee, 1966, op. cit., part 2.

34 New York Times, August 26, 1973, 1, 51; Humanist Manifestos I and II (Buffalo, N.Y.: Prometheus Books, 1973), 24-31.

${ }^{35}$ Quoted by Jacob Axelrad, Anatole France (New York: Harper \& Bros., 1944), 427 .

36F. J. Turner, 'Significance of the Frontier in American History,' 1894, reprinted in his Frontier and Section, ed. R. A. Billington (Englewood Cliffs, N.J.: Prentice-Hall, 1961), 37-62, at 62 . 
37 Henri Peyre, 'In Purgatory Still,' New York Times Book Fieview, Iecember 17, 1967, 4 .

${ }^{38}$ Van Wyck Brooks, The Ordeal of Mark Twain (New York: E.P. Tutton \& Co. , 1933), esp. ohap. 1; Lewis Leary, ed., A Casebook of Mark Twain's Wound (New York: Thomas Y. Crowell Co., 1962).

39 Mark Twain, The Mysterious Stranger, ed. W. M. Gibson (Berkeley: University of California Press, 1969), This is a more authentic edition than the original 1916 one.

40 Maxwell Geismar, Mark Twain: An American Prophet (Boston: Houghton Mifflin Co., 1970), 536 .

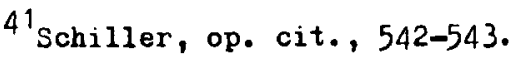

42 Irving Babbitt, On Being Creative (Boston: Houghton Mifflin Co., 1932), esp. xi-xiiv.

43 W. H. Coates and H.V. White, The Ordeal of Liberal Humanism (New York: McGraw-Hill Book Co., 1970), 232-233.

${ }^{44}$ Karl Marx, Early Writings $(1844-1846)$, trans. and ed. T.B. Bottomore (London: C.A. Watts \& Co., 1963), 155.

45 Ibid., 213.

${ }^{46}$ Karl Marx and Frederick Engels, The German Ideology (1846), trans. and ed. R. Pascal (London: Lawrence and Wishart, 1939).

47 Ibid., Basic Writings on Politics and Philosophy, ed. L.S. Feuer (Garden City, N.Y.: Doubleday \& Co., 1959), 248.

48 Lee, Toward Humanist Sociology, op. cit., chap. 3; 'Efforts at Revolution in Ireland,' paper presented before American Sociological Association, New York, N.Y., August 30, 1973.

${ }^{49}$ Marx and Engels, Ireland and the Irish Question, ed. R. Jixon (New York: International Publishers, 1972), 160-161. 
${ }^{50}$ Lee, 'Efforts at Revolution in Ireland,' op. cit.

${ }^{51}$ Marx, A Contribution to the Critique of Political Economy, 1873 (Chicago: Charles H. Kerr \& Co., 1904), 11-13.

52 Italics added; Marx and Engels, 1959, op. cit., 146.

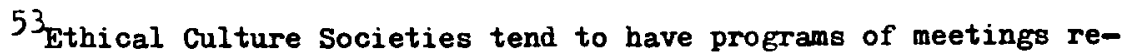
sembling those of Christian churches; American Humanist Association local units vary in program but usually have monthly speakers or discussion sessions plus the work of action committees on social concerns.

${ }^{54}$ C.W. Reese, The Meaning of Humanism (Buffalo, N.Y.: Prometheus Books, 1945), 34; see also Mason 01ds, 'John H. Dietrich: The Father of Religious Humanism,' Journal of the Liberal Ministry, XV, 1 (Winter 1975), 46-52.

$55_{\text {Blanshard, op. cit. }}$

56 J. H. Randall, Jr., 'Communication,' The Humanist, XXXIII (MarchApril 1973), 36.

57 Lloyd and Mary Morain, Humanism as the Next Step (Boston: Beacon Press, 1954); E. H. Wilson, 'Liberal Religion's Unfinished Business, ' Journal of the Liberal Ministry, XII, 3 (Fall 1972), 3-15.

${ }^{58}$ Corliss Lamont, The Philosophy of Humanism, 5th ed. (New York: Frederick Ungar Publ. Co., 1965); Paul Kurz, ed., Moral Problems in Contemporary Society, 2nd ed. (Buffalo, N.Y.: Prometheus Books, 1973); Kurz, The Fullness of Life (New York: Horizon Press, 1974).

59 Julian S. Huxley, Essays of a Humanist (New York: Harper \& Row, $1964), 280$.

60 B.F. Skinner and Carl Rogers, 'Some Issues Concerning the Control of Human Behavior: A Symposium' (Reprinted from Science, November 30, 1956, 1057-1066) in J.F. Glass and J.R. Staude, eds., Humanistic Society (Pacific Palisades, Calif.: Goodyear Publ. Co., 1972), 327349, at 335-336. 
$61_{\text {I bid. }, 345,348 .}$

${ }^{62}$ See also Skinner, Beyond Freedom and Dignity (New York: Bantam Books, 1971), and Walden Two (New York: IMacmillan Co., 130u).

${ }^{63}$ Skinner and Rogers, op. cit., $338,345$.

64.M. Jourard, 'A Humanistic Revolution in Psychology,' 1968, in Glass and Staude, op. cit., 15-19, at 18, 15.

65Ibid., Nisclosing Man to Himself, 2nd ed. (Princeton: Van Nostrand Reinhold Co., 1971); A.H. Maslow, Toward a Psychology of Being, 2nd ed. (Princeton: Van Nostrand, 1968), Motivation and Personality, 2nd ed (New York: Harper \& Row, 1970), and The Further keaches of Human Nature (New York: Viking Press, 1971).

${ }^{66}$ Lee, 1966, op. cit., chap. 22, Toward Humanist Sociology, op. cit., ohap. 2.

${ }^{67}$ Charles Booth, Labour and Life of the People (London: Williams \&Norgate, 1889-1891), I, II, Appendix.

68 R.E. Park, 'The City as a Social Laboratory,' in T.V. Smith and L.D. White, eds., Chicago: An Experiment in Social Science Research (Chicago: University of Chicago Press, 1929), 46.

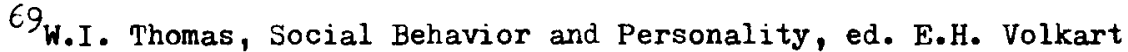
(New York: Social Science Research Council, 1951), 89 footnote 3 , 93-94; see Michael Parenti, 'Introduction to the Torchbook Edition,' in Thomas, The Unadjusted Girl (New York: Harper \& Row, 1967), viii-xxi.

70 W.F. Whyte, street Corner Society, 2nd ed. (Chicago: University of Chicago Press, 1955), appendix.

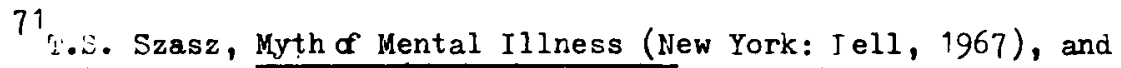
Ideolosy and Insanity (Garden City, N.Y.: Joubleday \& Co., T7TO); R. $T_{0}$ Laing, Self and Others, rev. ed. (liew York: Pantheon 3ooks, 137j).

72 Lee, 'On Context and Relevance,' in Glenn Jacobs, ed. 'The Participant Observer (New York: Georte Braziller, 19Ti), $3-16$.

ijuacobs, ibid., ix. 